\title{
Kleptoplasts mediate nitrogen acquisition in the sea slug Elysia viridis
}

\author{
Bart Teugels $^{1, *}$, Steven Bouillon ${ }^{2,3,4, *, * *}$, Bart Veuger $^{3}$, Jack J. Middelburg ${ }^{3}$, Nico Koedam ${ }^{1}$ \\ ${ }^{1}$ Laboratory of General Botany and Nature Management, and ${ }^{2}$ Department of Analytical and Environmental Chemistry, \\ Vrije Universiteit Brussel, Pleinlaan 2, 1050 Brussels, Belgium \\ ${ }^{3}$ Netherlands Institute of Ecology, Centre for Estuarine and Marine Ecology (NIOO-CEME), Yerseke 4401, The Netherlands \\ ${ }^{4}$ Katholieke Universiteit Leuven, Department of Earth and Environmental Sciences, 3001 Leuven, Belgium
}

\begin{abstract}
Kleptoplasty is a remarkable form of symbiosis whereby photosynthetically functional algal chloroplasts are retained by the host organism. Certain sacoglossan sea slugs form such associations and some species such as Elysia viridis (Montagu, 1804) can survive for months without access to their food algae. We report evidence for light-dependent assimilation of ammonium, nitrite, and urea (but not nitrate) in E. viridis with functional kleptoplasts. $\mathrm{N}$ uptake was decreased in slugs with reduced chloroplast densities, and after exposure to inhibitors of glutamine synthetase and glutamate synthetase. Incorporation of ${ }^{15} \mathrm{~N}$-labeled substrates was traced into individual hydrolyzable amino acids, with highest incorporation in glutamine-glutamate. $\mathrm{N}$ assimilation by kleptoplasts in multicellular hosts constitutes an additional mechanism which may contribute to the unique and long-lived functionality of these symbioses.
\end{abstract}

KEY WORDS: Kleptoplasty $\cdot$ Nitrogen assimilation $\cdot$ Sacoglossan $\cdot$ Elysia viridis

\section{INTRODUCTION}

The retention of functional chloroplasts (kleptoplasty) has been reported for certain heterotrophic dinoflagellates, foraminifera, and sacoglossan sea slugs (Rumpho et al. 2006). This association provides these organisms with 2 pathways for organic carbon acquisition: (1) by phagotrophy (in dinoflagellates) or grazing (in the case of foraminifera and Sacoglossa) and (2) through photosynthesis by the kleptoplasts and transfer of organic compounds to the host. The relative importance of these 2 pathways for sacoglossans is still uncertain (Raven et al. 2001). Kleptoplasts often show a short-lived functionality (implying the need for steady replacement as in most dinoflagellates), but in some cases - in dinoflagellates (Gast et al. 2007), foraminifera (Grzymski et al. 2002), and certain sacoglossans (e.g. Hinde \& Smith 1972, Rumpho et al. 2000) - can remain functional for several months.

In sacoglossans, kleptoplasts are stored intracellularly in the the digestive gland cells, and their longlived functionality enables the slugs to survive pro- longed periods without access to food, e.g. 3 mo in the case of Elysia viridis (see Hinde \& Smith 1972) which typically derives its chloroplasts from the coenocytic green alga Codium fragile (Williams \& Walker 1999, Trowbridge \& Todd 2001). The sustained functionality observed in certain species has led to the hypothesis that lateral gene transfer between the algal and host nucleus may have occurred (Hanten \& Pierce 2001, Mondy \& Pierce 2003), since - at least for E. chlorotica, which has been studied in more detail-the chloroplast genome does not hold the coding capacity for most of the chloroplast-targeted proteins necessary to sustain photosynthetic activity (Rumpho et al. 2006). Effective fixation of $\mathrm{CO}_{2}$ from the medium has been demonstrated for $E$. viridis and traced into glucose, carotenoids, xanthophylls (e.g. Trench 1975), and nonessential phospholipid fatty acids (authors' unpubl. data). Different hypotheses have been proposed to explain the advantages of kleptoplasty, but for some species it may certainly provide a mechanism to overcome periods when food algae are absent (e.g. Codium fragile, the primary food algae for E. viridis, can be 
absent during winter months), when access to food algae is restricted (e.g. for E. bangtawaensis which may at times be restricted to high intertidal pools; see Swennen 1997), or during periods when the food algae are calcifying (e.g. in the case of E. timida, see Giménez-Casalduero \& Muniain 2008 and references therein). However, the question arises of how the host metabolism can be sustained for such periods: while the kleptoplasts may provide carbon substrates to the host (Trench \& Smith 1970, Trench et al. 1973), this could rapidly lead to nitrogen starvation. So far, no studies have addressed the possibility of inorganic nitrogen or urea acquisition by these symbioses.

We conducted a series of comparative experiments on Elysia viridis (Fig. 1) with various densities of functional kleptoplasts (as indicated by their coloration ranging from dark green in feeding individuals to light yellow in those starved for several weeks or months) which were exposed to ${ }^{15} \mathrm{~N}$-labeled ammonium, urea, nitrite, and nitrate under dark and light conditions. Uptake and incorporation of the ${ }^{15} \mathrm{~N}$ label was traced into bulk tissues and individual hydrolyzable amino acids. A general scheme showing the proposed pathways of $\mathrm{N}$ assimilation is shown in Fig. 2.

\section{MATERIALS AND METHODS}

Elysia viridis and several algal species, including the host alga Codium fragile (Suringar) Hariot were collected in the Grevelingenmeer (the Netherlands) by SCUBA diving and snorkelling, and were kept in the laboratory in various $15 \mathrm{l}$ aquaria in either natural or artificial seawater (ASW). All enrichment experiments were conducted in ASW, typically filtered through $0.22 \mu \mathrm{m}$ Millipore filters to minimize any bacterial activ-

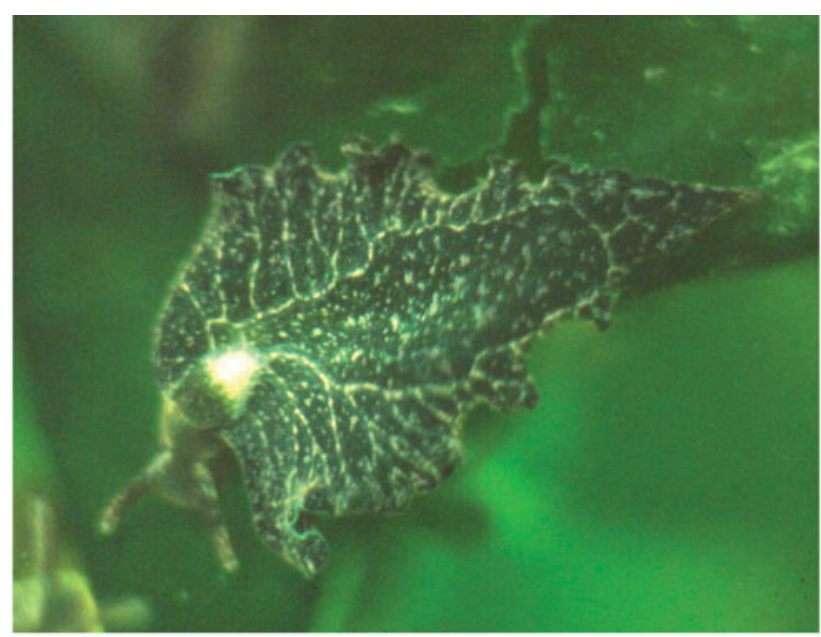

Fig. 1. Elysia viridis. Dorsal view, showing the uniform distribution of chloroplasts

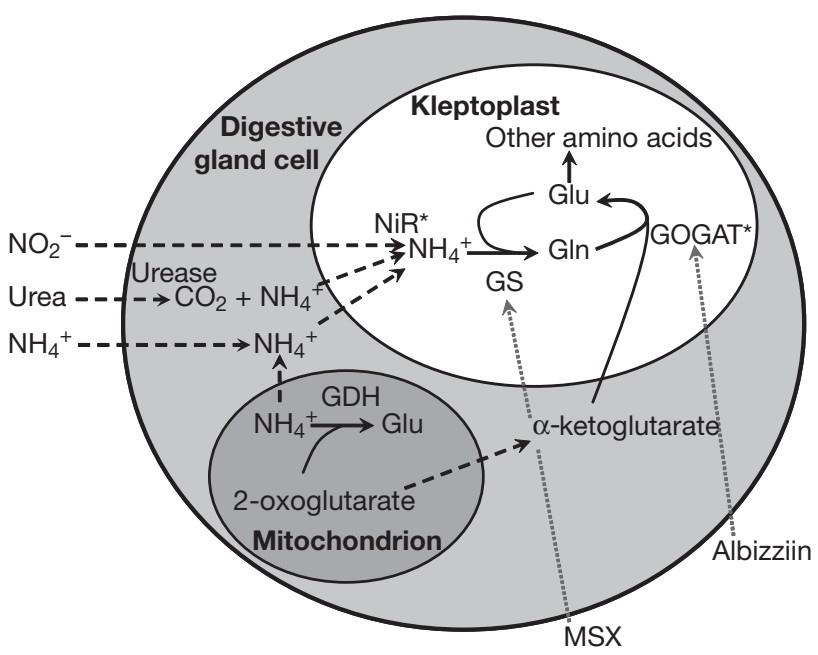

Fig. 2. Elysia viridis. Schematic representation of proposed pathways of nitrogen acquisition. NiR: nitrite reductase, GS: glutamine synthetase, GOGAT: glutamate synthetase, Glu: glutamate, Gln: glutamine, GDH: glutamine dehydrogenase, MSX: methionine sulfoximine. Dotted arrows indicate the sites inhibited by MSX and albizziin, broken lines represent transport of solutes, and solid lines represent metabolic reactions. *Processes expected to be light-dependent (see 'Results and discussion' for details)

ity. For the various ${ }^{13} \mathrm{C}$ and ${ }^{15} \mathrm{~N}$ labeling experiments, the ASW was spiked with either $\mathrm{NaH}^{13} \mathrm{CO}_{3}(1 \mathrm{mmol}$ $\mathrm{I}^{-1}$ above background concentration) and/or $\mathrm{K}^{15} \mathrm{NO}_{3}$ $\left(40 \mu \mathrm{mol} \mathrm{l} \mathrm{l}^{-1}\right), \mathrm{K}^{15} \mathrm{NO}_{2}\left(40\right.$ to $\left.70 \mu \mathrm{mol} \mathrm{l}^{-1}\right), \mathrm{CO}\left({ }^{15} \mathrm{NH}_{3}\right)_{2}$ $\left(20 \mu \mathrm{mol} \mathrm{l}^{-1}\right)$, and ${ }^{15} \mathrm{NH}_{4} \mathrm{Cl}\left(10\right.$ to $\left.40 \mu \mathrm{mol} \mathrm{l}^{-1}\right)$. The incubation media were prepared in $250 \mathrm{ml}$ glass Erlenmeyer flasks and covered with Parafilm after addition of the test individuals. Experiments were run under natural light conditions (i.e. background light being adjacent to the window in the laboratory) and for all dark experiments, the Erlenmeyer flasks containing the media were entirely wrapped in aluminum foil. All experiments were run over short time frames $(\leq 30 \mathrm{~h})$. To verify the effect of specific enzyme inhibitors on the apparent uptake of $\mathrm{NH}_{4}{ }^{+}$, E. viridis were first exposed to ASW supplemented for 3 to $4 \mathrm{~h}$ with either methionine sulfoximine (MSX, $\left.10 \mathrm{mmol} \mathrm{l}^{-1}\right)$ or albizziin $\left(15 \mathrm{mmol} \mathrm{l}^{-1}\right)$, which inhibit glutamine synthetase (GS) and glutamate synthetase (GOGAT), respectively (Turnbull et al. 1996). These slugs were then transferred to incubation media spiked with ${ }^{15} \mathrm{NH}_{4} \mathrm{Cl}$ as described earlier in this paragraph. After exposure to the labeled substrates, E. viridis were taken out of the medium and rinsed thoroughly with ASW. The slugs were left in ASW for $4 \mathrm{~h}$, during which time the ASW was replaced every 30 min and slugs were rinsed each time to remove all adsorbed label as much as possible. Slugs were then frozen, freeze-dried and ground to a fine powder using a mortar and pestle. Subsamples for $\delta^{13} \mathrm{C}$ were acidified with a few drops of dilute 
$(5 \%) \mathrm{HCl}$ before analysis to remove any traces of carbonates and were then re-dried. $\delta^{13} \mathrm{C}$ and $\delta^{15} \mathrm{~N}$ analyses were performed with a ThermoFinnigan Flash1112 elemental analyzer, coupled to a ThermoFinnigan Delta+XL isotope ratio mass spectrometer (IRMS) via a Conflo III interface.

For the determination of ${ }^{15} \mathrm{~N}$ incorporation into hydrolyzable amino acids, a modified protocol of Veuger et al. (2005) was used. Approximately $0.5 \mathrm{mg}$ of homogenized dry tissue was hydrolyzed in $1.5 \mathrm{ml} 6 \mathrm{~mol} \mathrm{l}^{-1} \mathrm{HCl}$ under $\mathrm{N}_{2}$ atmosphere for $20 \mathrm{~h}$ at $110^{\circ} \mathrm{C}$. After gentle evaporation, samples were derivatized with isopropanol and pentafluoropropionic acid, and further purified by solvent extraction. Relative concentrations and ${ }^{15} \mathrm{~N}$ incorporation were analyzed using gas chromatography/combustion/IRMS (GC-C-IRMS) using an HP6809 GC coupled to a Thermo Delta+XL IRMS (see Veuger et al. 2005). D-alanine, a bacteria-specific amino acid, was present only in trace amounts, and D:L-alanine ratios were below the hydrolysis-induced racemization background (Veuger et al. 2005), indicating that bacterial biomass, and therefore the bacterial contribution to ${ }^{15} \mathrm{~N}$ incorporation, was negligible. During hydrolysis, glutamine (Gln) is converted to glutamate (Glu), so we report data for the Glu-Gln peak which refers to both Glu and Gln.

Stable isotope ratios are expressed relative to the conventional standards (Vienna PeeDee Belemnite and atmospheric $\mathrm{N}_{2}$ ) as $\delta$ values, defined as:

$$
\delta X=\frac{X_{\text {sample }}-X_{\text {standard }}}{X_{\text {standard }}} \times 10^{3}(\%)
$$

where $X={ }^{13} \mathrm{C}:{ }^{12} \mathrm{C}$ or ${ }^{15} \mathrm{~N}:{ }^{14} \mathrm{~N}$

It should be stressed that our experiments were not designed to make quantitative estimates of $\mathrm{N}$ uptake or assimilation (i.e. the absolute amount of ${ }^{15} \mathrm{~N}$ assimilation per unit of biomass and time), but to verify whether we could find evidence for $\mathrm{N}$ assimilation when using different $\mathrm{N}$ substrates, and how this was influenced by light conditions, density of kleptoplasts (i.e. coloration), and exposure to inhibitors for specific potentially involved enzymatic pathways. We used $t$-tests to evaluate differences between experimental treatments when levels of ${ }^{15} \mathrm{~N}$ enrichments in the substrates were similar (e.g. light versus dark, exposed to inhibitors or not). As the levels of ${ }^{15} \mathrm{~N}$ enrichment in the substrate and incubation conditions were not always similar between experiments with different substrates, absolute levels of ${ }^{15} \mathrm{~N}$ enrichments are not always to be compared directly. Enrichment levels are expressed as $\Delta \delta^{15} \mathrm{~N}$ (or $\Delta \delta^{13} \mathrm{C}$ ) values, where $\Delta \delta^{15} \mathrm{~N}=\delta^{15} \mathrm{~N}_{\text {exposed }}-\delta^{15} \mathrm{~N}_{\text {control, }}$, where the $\delta^{15} \mathrm{~N}$ of control organisms refers to those not exposed to ${ }^{15} \mathrm{~N}$-labeled substrates (and equivalent for ${ }^{13} \mathrm{C}$ ), or in the case of the inhibitor experiments, those exposed to ${ }^{15} \mathrm{~N}$-labeled substrates but not to the specific inhibitors used.

\section{RESULTS AND DISCUSSION}

The functionality of the kleptoplasts in our experimental organisms was demonstrated by exposure to ${ }^{13} \mathrm{C}$-bicarbonate in the medium, whereby (1) darkgreen Elysia viridis (indicative of high chloroplast densities) exhibited significantly higher ${ }^{13} \mathrm{C}$ uptake (i.e. photosynthesis) than small, yellow, starved individuals (i.e. with degraded chloroplasts), and (2) uptake of ${ }^{13} \mathrm{C}$ was significantly higher under light conditions compared to dark treatments, and this was most pronounced for green individuals (Fig. 3).

Green Elysia viridis exposed to different ${ }^{15} \mathrm{~N}$-labeled substrates showed clearly distinct ${ }^{15} \mathrm{~N}$-labeling patterns under dark and light conditions for the various $\mathrm{N}$ substrates (Fig. 4). No ${ }^{15} \mathrm{~N}$ uptake was found after exposure to ${ }^{15} \mathrm{~N}$-nitrate $(\mathrm{p}>0.2)$, whereas significant uptake of ${ }^{15} \mathrm{~N}$ from ammonium $(\mathrm{p}<0.001)$, urea $(\mathrm{p}<$ $0.001)$, and nitrite $(\mathrm{p}<0.05)$ was detected. Moreover, the relative uptake rates were higher in light compared to dark incubations for both nitrite and ammonium ( $p=0.01$ and $p=0.03$, respectively), but less pronounced in the case of urea $(p=0.06$; Fig. 4$)$. The light-dependent uptake patterns of ammonium and nitrite are consistent with the expected presence of the relevant enzymes (i.e. nitrite reductase $[\mathrm{NiR}]$ and GOGAT) in the kleptoplasts, since reduced ferredoxin (formed in the photosynthetic electron transport chain) are used as electron donors in their reactions (Grossman \& Takahashi 2001). Similarly, the reported presence of ureases in the slug (Pedrozo et al. 1996, Pierce et al. 1996), which convert urea to ammonium and

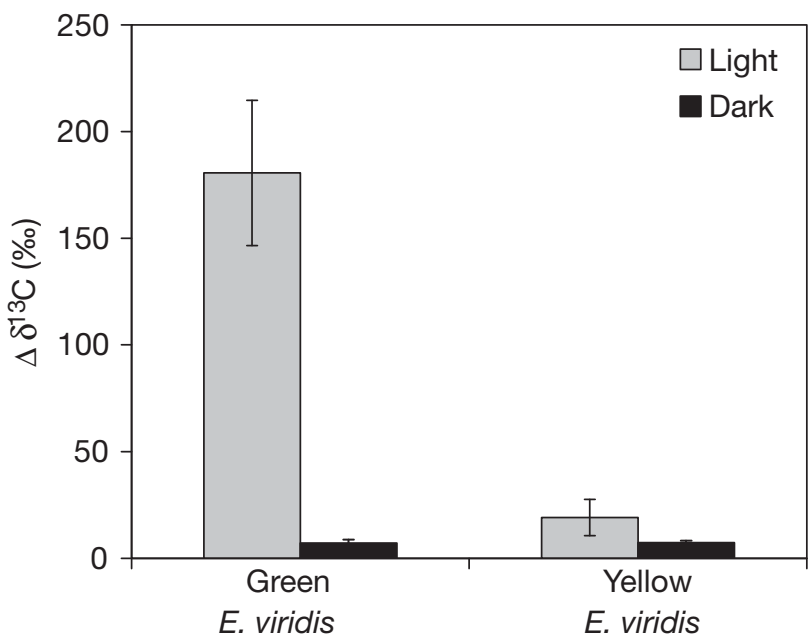

Fig. 3. Elysia viridis. Enrichment in ${ }^{13} \mathrm{C}$ for green and yellow individuals after exposure to artificial seawater spiked with $1 \mathrm{mmol} \mathrm{l}^{-1}{ }^{13} \mathrm{C}$-bicarbonate for $30 \mathrm{~h}$ in either light or dark conditions. Error bars: $1 \mathrm{SD}$ ( $\mathrm{n}=3$ for green individuals, $\mathrm{n}=2$ for yellow individuals) 


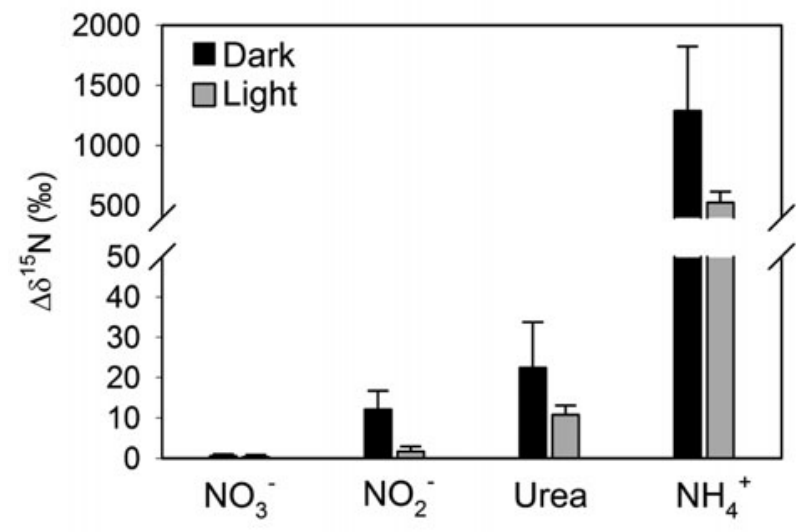

Fig. 4. Elysia viridis. ${ }^{15} \mathrm{~N}$ labeling of green individuals after exposure to artificial seawater spiked with either $40 \mathrm{\mu mol}^{-1}$ $\mathrm{K}^{15} \mathrm{NO}_{2}, 40 \mu \mathrm{mol} \mathrm{l}^{-1} \mathrm{~K}^{15} \mathrm{NO}_{3}, 40 \mu \mathrm{mol} \mathrm{l}^{-1}{ }^{15} \mathrm{NH}_{4} \mathrm{Cl}$, or $20 \mu \mathrm{mol}$ $\mathrm{l}^{-1} \mathrm{CO}\left({ }^{15} \mathrm{NH}_{2}\right)_{2}$ for $20 \mathrm{~h}$ in either light or dark conditions. Error bars: $1 \mathrm{SD}(\mathrm{n}=3)$

$\mathrm{CO}_{2}$, offers a plausible explanation for the labeling pattern after exposure to ${ }^{15} \mathrm{~N}$-urea (Fig. 4). The absence of nitrate uptake is consistent with the expected cytoplasmic localization of nitrate reductase in Codium fragile (Pedrozo et al. 1996). Direct evidence for assimilation rather than merely uptake of the ${ }^{15} \mathrm{~N}$ label was provided by amino acid $\delta^{15} \mathrm{~N}$ signatures, which were analyzed for the individuals exposed to labeled nitrite and ammonium (Fig. 5). Moreover, it is worth noting that in both cases, the degree of ${ }^{15} \mathrm{~N}$ labeling in GluGln was markedly higher than observed in bulk tissues (Fig. 5), stressing the importance of amino acids as primary compounds for the ${ }^{15} \mathrm{~N}$ assimilation observed. All amino acids analyzed except lysine showed significant incorporation of the ${ }^{15} \mathrm{~N}$, with the majority of excess ${ }^{15} \mathrm{~N}$ $(\sim 60 \%)$ in Gln-Glu, followed by aspartic acid and L-alanine (Fig. 6). This pattern identifies Gln and/or Glu (see 'Materials and methods': the hydrolysis procedure results in conversion of Gln to Glu) as the primary amino acid(s) for $\mathrm{N}$ incorporation, with subsequent transfer of the ${ }^{15} \mathrm{~N}$ label to other amino acids through transferase reactions. These patterns are again consistent with the GS-GOGAT pathway proposed, although it must be stressed that $\mathrm{NH}_{4}{ }^{+}$incorportation may also take place through the glutamine dehydrogenase (GDH) pathway in the mitochondria (Fig. 2). This process has indeed been reported in marine mollusks (e.g. Sadok et al. 2001, Reiss et al. 2005) and could thus explain part of the $\mathrm{NH}_{4}{ }^{+}$uptake observed. However, our further experiments with selective inhibitors for GS and GOGAT (see paragraph after next) clearly demonstrate that the GS-GOGAT pathway is at least partly involved in the observed $\mathrm{NH}_{4}{ }^{+}$assimilation patterns.
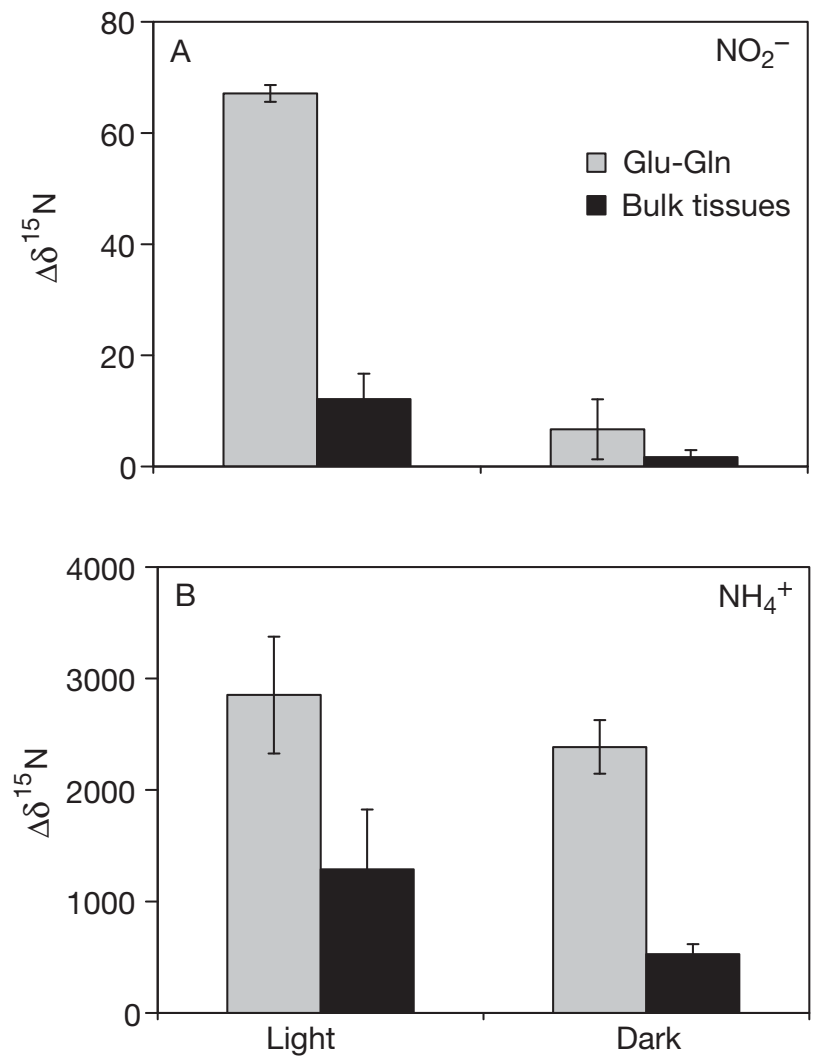

Fig. 5. Elysia viridis. Enrichment in ${ }^{15} \mathrm{~N}$ in hydrolyzable glutamine/glutamate and bulk tissues for green individuals exposed to (A) ${ }^{15} \mathrm{~N}$-labeled nitrite or (B) ${ }^{15} \mathrm{~N}$-labeled ammonium under light and dark conditions. Error bars: $1 \mathrm{SD}$

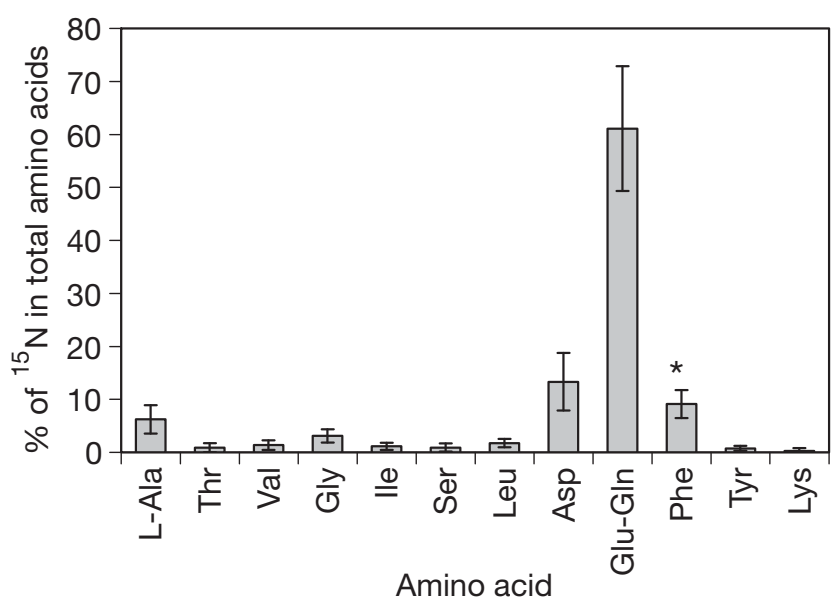

Fig. 6. Elysia viridis. Relative incorporation of ${ }^{15} \mathrm{~N}$ from ${ }^{15} \mathrm{~N}$ ammonium in different hydrolyzable amino acids, for green individuals incubated under both light and dark conditions (pooled data, since labeling patterns were similar, $\mathrm{n}=4$ ). Note that during hydrolysis, Gln is converted to Glu, so the Glu-Gln peak refers to both Glu and Gln. *Partial overlap of Phe with the Glu-Gln peak occurs, and part of the ${ }^{15} \mathrm{~N}$ reported for Phe may be due to high labeling of Glu-Gln. Error bars: $1 \mathrm{SD}$ 
A second series of experiments using Elysia viridis with different coloration (i.e. with a variable amount of functional chloroplasts) provided further support for a role of kleptoplasts in $\mathrm{N}$ acquisition. In green $E$. viridis, we found a larger ${ }^{15} \mathrm{~N}$ uptake in light compared to dark incubations ( $p<0.02)$, whereas such a difference was not observed in yellow individuals, which had not had access to their host algae for a longer period of time and thus have a reduced amount of remaining chloroplasts $(p=0.09$; Fig. 7A). Because the yellow slugs were observed to be less active, we wanted to exclude the possibility that the animals' general condition rather than the absence or reduction of functional chloroplasts might have influenced our results. Therefore, a new control experiment was carried out to compare ${ }^{15} \mathrm{~N}$ assimilation between green- and red-colored E. viridis. Green E. viridis had been held in the laboratory with access to the normal food algae, while the coloration in (field-collected) red E. viridis was due to feeding on red algae such as Dasysiphonia sp. As the red specimens had had no access to Codium fragile for $\sim 4$ mo in the field (the occurrence of $C$. fragile is seasonal) and since $E$. viridis is not known to derive functional kleptoplasts from non-green algae (Williams \&
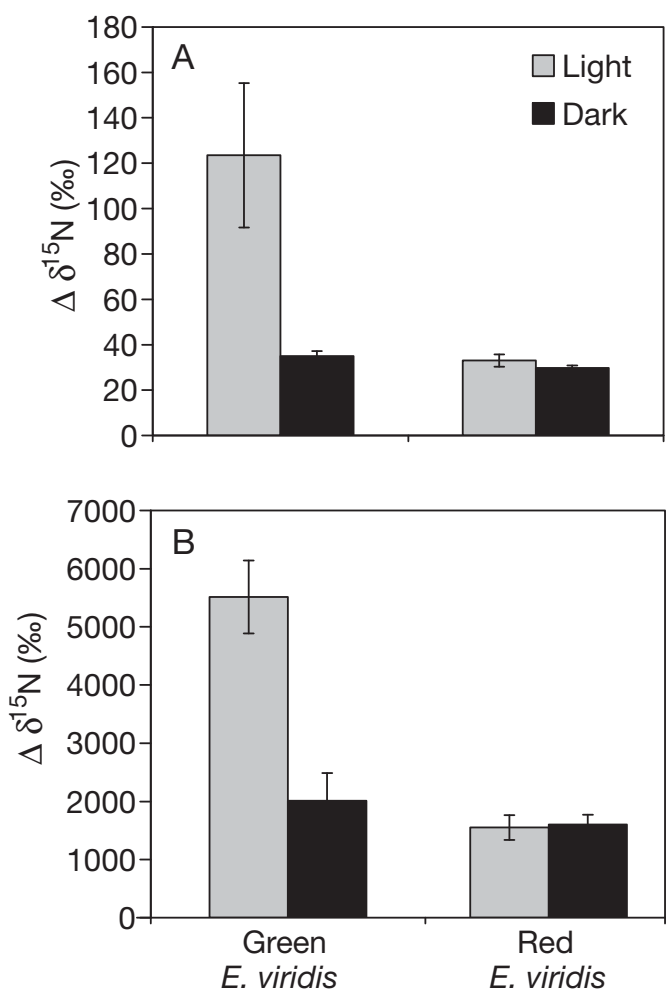

Fig. 7. Elysia viridis. ${ }^{15} \mathrm{~N}$ labeling of individuals of different coloration after exposure to artificial seawater spiked with (A) $70 \mu \mathrm{mol} \mathrm{l} \mathrm{l}^{-1}{ }^{15} \mathrm{~N}$-nitrite for $30 \mathrm{~h}$, or (B) $25 \mu \mathrm{mol} \mathrm{l} \mathrm{l}^{-1}{ }^{15} \mathrm{~N}$ ammonium for $7 \mathrm{~h}$ in either light or dark conditions. Error bars: $1 \mathrm{SD}(\mathrm{n}=3)$
Walker 1999), any functionality of their possibly remaining chloroplasts would be reduced. Since they had actively fed on other algae and were of similar size than usual green E. viridis, we can expect these to represent healthy, active but functional chloroplastfree individuals, i.e. ideal control specimens. Consistent with expectations for kleptoplast involvement in $\mathrm{N}$ uptake, red E. viridis took up significantly less ${ }^{15} \mathrm{~N}$ ammonium than green $E$. viridis in the light $(\mathrm{p}<0.005$; Fig. 7B), and in contrast to green E. viridis, red-colored specimens did not show any difference in $\mathrm{N}$ uptake between light and dark conditions $(\mathrm{p}<0.001$ and $\mathrm{p}=$ 0.38, respectively; Fig. 7B).

In order to link the observed uptake to a specific assimilation process, Elysia viridis were exposed to the GS inhibitor MSX and the GOGAT inhibitor albizziin. In both treatments, significantly less ammonium uptake was observed compared with control animals (Fig. 8 ; $t$-test on the $\delta^{15} \mathrm{~N}$ data: $\mathrm{p}=0.04$ and $\mathrm{p}=0.001$ for the MSX and albizzin experiment, respectively), confirming that at least a part of the ammonium uptake can be explained by GS and GOGAT activity. Since GOGAT has been reported from higher heterotrophic organisms in only a few cases (see Pedrozo et al. 1996), these experiments provide further evidence that the kleptoplasts derived from Codium fragile are at least in part responsible for the observed $\mathrm{N}$ uptake in E. viridis.

Our results offer different lines of evidence for dissolved nitrogen acquisition by Elysia viridis with functional kleptoplasts, and this is the first report for this function for kleptoplasts in multicellular hosts. Earlier studies demonstrated the presence (but not functionality) of nitrate reductase in the benthic foraminifer Nonionella stella (Grzymski et al. 2002), which retains chromoplasts derived from diatoms and occurs in the aphotic zone. Uptake of dissolved inorganic and organic $\mathrm{N}$ species has also been reported for the dinoflagellate Pfiesteria piscicida, which retains chloroplasts from the cryptophyte Rhodomonas sp. (Lewitus et al. 1999). Although the function of kleptoplasts was originally considered to be limited to providing camouflage (in the case of sacoglossans), synthesizing defense compounds, and $\mathrm{CO}_{2}$ fixation (Rumpho et al. 2006), the present study now clearly documents that the nitrogen acquisition function is not limited to unicellar organisms (Lewitus et al. 1999, Grzymski et al. 2002), but that it also exists in animals. The ability to assimilate dissolved $\mathrm{N}$ is likely to be beneficial to maintaining a long-lived functional association, and in particular for species which at times have no or limited access to their food algae and may thus become entirely dependent on kleptoplasty for a certain period of time (see examples cited in 'Introduction'). De novo protein synthesis has been shown to 

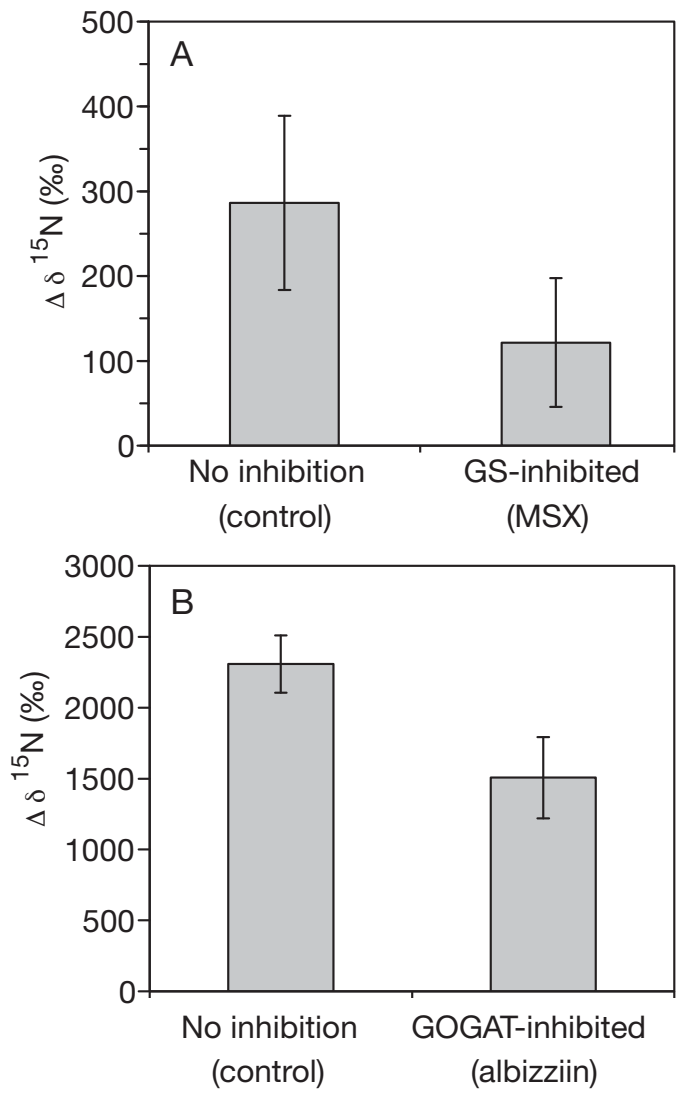

Fig. 8. Elysia viridis. ${ }^{15} \mathrm{~N}$ labeling of green individuals during exposure (which started $4 \mathrm{~h}$ prior) to (A) MSX $\left(10 \mathrm{mmol} \mathrm{l}^{-1}\right.$ ) or (B) albizziin $\left(15 \mathrm{mmol} \mathrm{l}^{-1}\right)$ prior to incubation for 21 and $25 \mathrm{~h}$, respectively, in artificial seawater amended with ${ }^{15} \mathrm{~N}$-ammonium under light conditions. Error bars: $1 \mathrm{SD}(\mathrm{n}=5)$. Note that $\Delta \delta^{15} \mathrm{~N}$ in the control organisms is different for both experiments due to different enrichment levels and incubation times. GS: glutamine synthetase, GOGAT: glutamate synthetase, MSX: methionine sulfoximine

occur for plastid-encoded membrane proteins even after 8 mo of starvation in Elysia chlorotica (Mujer et al. 1996), and this would appear unlikely without an external supply of nitrogen. The approach used here offers exciting possibilities for future studies unravelling the biosynthesis and transfer of metabolites between kleptoplasts and their hosts.

Acknowledgments. We thank P. van Bragt, H. van Pottelbergh, S. Juvyns, P. Meeremans, and S. Teugels for their help with collecting Elysia viridis, and R. de Schutter and R. Merken for practical help. S.B. was supported by a postdoctoral fellowship from the Research Foundation Flanders (FWO-Vlaanderen), and this research was also supported by the Netherlands Organisation for Scientific Research (NWO). D. P. Gillikin, F. Bossuyt, F. Dehairs, and 2 anonymous referees provided excellent constructive suggestions to an earlier version of this manuscript. This is publication 4384 of the Netherlands Institute of Ecology (NIOO-KNAW).

\section{LITERATURE CITED}

Gast RJ, Moran DM, Dennett MR, Caron DA (2007) Kleptoplasty in an Antarctic dinoflagellate: caught in evolutionary transition? Environ Microbiol 9:39-45

> Giménez-Casalduero F, Muniain C (2008) The role of kleptoplasts in the survival rates of Elysia timida (Risso, 1818): (Sacoglossa, Opisthobranchia) during periods of food shortage. J Exp Mar Biol Ecol 357:181-187

Grossman A, Takahashi H (2001) Macronutrient utilization by photosynthetic eukaryotes and the fabric of interactions. Annu Rev Plant Physiol Plant Mol Biol 52:163-210

Grzymski J, Schofield OM, Falkowski PG, Bernhard JM (2002) The function of plastids in the deep-sea benthic foraminifer, Nonionella stella. Limnol Oceanogr 47: $1569-1580$

Hanten JJ, Pierce SK (2001) Synthesis of several light-harvesting complex I polypeptides is blocked by cycloheximide in symbiotic chloroplasts in the sea slug, Elysia chlorotica (Gould): a case for horizontal gene transfer between alga and animal? Biol Bull (Woods Hole) 201: $34-44$

Hinde R, Smith DC (1972) Persistence of functional chloroplasts in Elysia viridis (Opisthobranchia, Sacoglossa). Nat New Biol 239:30-31

Lewitus AJ, Willis BM, Hayes KC, Burkholder JM, Glasgow HB, Gilbert PM, Burke MK (1999) Mixotrophy and nitrogen uptake by Pfiesteria piscicida (Dinophyceae). J Phycol 35:1430-1437

Mondy WL, Pierce SK (2003) Apoptotic-like morphology associated with annual synchronized death in kleptoplastic sea slugs (Elysia chlorotica). Invertebr Biol 122:126-137

Mujer CV, Andrews DL, Manhart JR, Pierce SK, Rumpho ME (1996) Chloroplast genes are expressed during intracellular symbiotic association of Vaucheria litorea plastids with the sea slug Elysia chlorotica. Proc Natl Acad Sci USA 93: 12333-12338

Pedrozo HA, Schwartz Z, Dean DD, Wiederhold ML, Boyan BD (1996) Regulation of statoconia mineralization in Aplysia californica in vitro. Connect Tissue Res 35: $317-323$

Pierce SK, Biron RW, Rumpho ME (1996) Endosymbiotic chloroplasts in molluscan cells contain proteins synthesized after plastid capture. J Exp Biol 199:2323-2330

> Raven JA, Walker DI, Jensen KR, Handley LL, Scrimgeour SM, McInroy SG (2001) What fraction of organic carbon in sacoglossans is obtained from photosynthesis by kleptoplastids? An investigation using the natural abundance of stable carbon isotopes. Mar Biol 138:537-545

Reiss PM, Pierce SK, Bishop SH (2005) Glutamate dehydrogenases from tissues of the ribbed mussel Modiolus demissus: ADP activation and possible physiological significance. J Exp Zool 202:253-257

Rumpho ME, Summer EJ, Manhart JR (2000) Solar-powered sea slugs. Mollusc/algal chloroplast symbiosis. Plant Physiol 123:29-38

Rumpho ME, Manhart JR, Lee J (2006) The kleptoplast. In: Wise RR, Hoober JK (eds) The structure and function of plastids. Springer, Berlin, p 451-475

Sadok S, Uglow RF, Haswell SJ (2001) Glutamate dehydrogenase activity in Mytilus edulis: the effects of hyperammonia. Vie Milieu 51:189-194

Swennen C (1997) Two new gastropods, Elysia bangtawaensis and E. siamensis from southern Thailand (Ophistobranchia, Sacoglossa, Elysiidae). Bull Zool Mus Univ Amst 16:33-39

Trench RK (1975) Of 'leaves that crawl': functional chloro- 
plasts in animal cells. Symp Soc Exp Biol 29:229-266

Trench RK, Smith DC (1970) Synthesis of pigment in symbiotic chloroplasts. Nature 227:196-197

Trench RK, Boyle JE, Smith DC (1973) The association between chloroplasts of Codium fragile and the mollusc Elysia viridis. II. Chloroplast ultrastructure and photosynthetic carbon fixation in E. viridis. Proc R Soc Lond 184:63-81

Trowbridge CD, Todd CD (2001) Host-plant change in marine specialist herbivores: ascoglossan sea slugs on introduced macroalgae. Ecol Monogr 71:219-243

Turnbull MH, Goodall R, Stewart GR (1996) Evaluating the

Editorial responsibility: Michael Kühl,

Helsingør, Denmark contribution of glutamate dehydrogenase and the glutamate synthase cycle to ammonia assimilation by four ectomycorrhizal fungal isolates. Aust J Plant Physiol 23: 151-159

Veuger B, Middelburg JJ, Boschker HTS, Houtekamer M (2005) Analysis of ${ }^{15} \mathrm{~N}$ incorporation into D-alanine: a new method for tracing nitrogen uptake by bacteria. Limnol Oceanogr Methods 3:230-240

Williams SI, Walker DI (1999) Mesoherbivore-macroalgal interactions: feeding ecology of sacoglossan sea slugs (Mollusca, Opisthobranchia) and their effects on their food algae. Oceanogr Mar Biol Annu Rev 37:87-128

Submitted: October 17, 2007; Accepted: August 18, 2008

Proofs received from author(s): September 12, 2008 